\title{
HAL YANG RUMPANG DAN TIMPANG DALAM KEBIJAKAN PERENCANAAN BAHASA JAWA
}

\author{
Wahyu Widodo* \\ Universitas Brawijaya \\ wahyu_widodo@ub.ac.id; wahyuheningdiri@gmail.com
}

\begin{abstract}
Abstrak
Kongres bahasa Jawa telah diadakan selama lima kali dalam kurun waktu 1991-2011. Hal itu menandakan bahwa ada upaya untuk menguatkan identitas Jawa melalui serangkaian program rekayasa bahasa. Ada asumsi bahwa masyarakat Jawa, terutama generasi mudanya, cenderung beralih dari masyarakat yang bilingual menjadi monolingual (Cohn \& Ravindranath, 2014). Apakah ini berarti secara internal bahasa Jawa memang tidak mampu menjawab tantangan global dan mengalami 'impotensi dan komplikasi' (Djatmika, 2010)? Artikel ini berusaha menjawab pertanyaan berikut: Hambatan-hambatan apakah yang dialami bahasa Jawa dalam proses menuju pematangan dan pembinaan bahasa tersebut? Artikel ini dilandaskan pada sebuah argumen bahwa impian elite pemangku kepentingan bahasa Jawa tentang pembinaan dan pengembangan bahasa Jawa melalui program rekayasa bahasa tidak dibarengi dengan 'mimpi kolektif' masyarakat penuturnya. Sumber data yang digunakan dalam artikel ini adalah dokumen hasil Kongres Bahasa Jawa I-V dan dokumen kebijakan pemerintah daerah yang terkait dengan pelestarian bahasa Jawa.
\end{abstract}

Kata Kunci: hambatan, ketimpangan kebijakan, pembinaan dan pengembangan bahasa Jawa

\begin{abstract}
There have been five congresses on Javanese language from 1991 to 2011. This indicates that there has been an effort to strengthen the Javanese identity through language engineering programs. There is an assumption that the Javanese people, especially the younger generation, nowadays tend to be monolingual than bilingual (Cohn \& Ravindranath, 2014). Is Javanese language internally unable to face globalization challenges, and as a result it suffers from "impotence" and "complication"? (Djatmika, 2010). This article attempts to address the following question: What are the obstacles faced by Javanese language during its process of development? This article is based on the argument that the Javanese language planning through the language engineering program does not incorporate the 'collective dream' of its native speakers. The sources of data for this article come from the documents of Javanese congresses I-V and language policy documents pertaining to Javanese language preservation.
\end{abstract}

Keywords: obstacles, policy imbalance, Javanese language development project

\section{PENDAHULUAN}

Bahasa Jawa (selanjutnya disebut BJ) merupakan bahasa yang memiliki penutur sebanyak 84.308.740 (Lewis, dkk., 2013). BJ merentang di tiga provinsi, yakni Jawa Timur, Jawa Tengah, dan DIY. Selain itu, BJ juga digunakan di sebagian provinsi di Indonesia seperti Sulawesi Selatan, Sumatera Utara, Jambi, Aceh, Nias, Lampung, dan Kalimantan. BJ juga digunakan di negara Suriname, Malaysia, dan Kaledonia Baru. BJ memiliki kekayaan variasi 
dialek, yakni 47 varian dialek (Laksono, 2011, hlm. 66). Kelimpahan sastra tulis dan lisan yang berakar pada kesenian tradisi juga berkembang di dusun dan menembus tembok istana keraton, sehingga pantaslah jika BJ disebut oleh Sudaryanto (1992, hlm. 9) sebagai bahasa yang mampu mengungkap kekayaan jiwa penutur-penuturnya. BJ menempuh perjalanan takdirnya hingga kini, yang memasuki era globalisasi. BJ berbenturan dengan saudara mudanya, yakni bahasa Indonesia dan juga menghadapi tamu baru yang perkasa, yakni bahasa Inggris dan bahasabahasa asing lainnya. Kompetisi pun tak terelakkan sehingga saat ini BJ tersisih. Ratap-tangis akibat kemungkinan gugur dan lenyapnya BJ di tengah masyarakat telah banyak disampaikan oleh para ahli, misalnya Padmosoekotjo (1956), Kadarisman (2008, 2012), Subroto, dkk (2008), Sumarlam (2011), dan pakar lainnya.

Pelembagaan kekhawatiran terhadap lenyapnya BJ di tengah masyarakat digelar oleh tiga provinsi (Jawa Timur, Jawa Tengah, dan DIY). Ketiga provinsi ini sejak tahun 1991 menyepakati adanya Kongres Bahasa Jawa (selanjutnya disebut KBJ). KBJ digelar untuk memberi saran dan rekomendasi bagi pemangku kepentingan (dalam hal ini bupati/walikota dan gubernur) untuk melaksanakan beberapa kebijakan pelestarian dan penyelamatan BJ. Selama kurun waktu 1991-2011, KBJ telah lima kali digelar dan menghasilkan beberapa rekomendasi yang ampuh sebagai penangkal lenyapnya BJ dan tradisi yang berpijak pada BJ. Akan tetapi, masyarakat penutur BJ, terutama generasi mudanya, mengalami penurunan penguasaan kompetensi tingkat tutur dalam BJ (Subroto, dkk, 2008, hlm. 94 ; Kadarisman, 2012, hlm. 249). Selain itu, generasi muda Jawa bergeser dari dwibahasawan (Jawa dan Indonesia) menjadi ekabahasawan (bahasa Indonesia saja) (Cohn dan Ravindranath, 2014, hlm. 138). Apa yang sesungguhnya sedang dialami oleh BJ? Apakah ia secara internal memang tidak mempunyai perkakas untuk menjawab tantangan global dan mengalami 'impotensi dan komplikasi' sebagaimana disampaikan oleh Djatmika (2010, hlm. 167)? Mengapa pula setiap rekomendasi KBJ berlalu tanpa bekas dan menguap tanpa ada pelaksanaan program yang nyata?

Artikel ini berusaha menjawab pertanyaan "hambatan-hambatan apakah yang dialami BJ dalam proses menuju pematangan dan pembinaan bahasa tersebut?" Artikel ini dilandaskan pada sebuah argumen bahwa impian elite pemangku kepentingan BJ tentang pembinaan dan pengembangan $\mathrm{BJ}$ melalui program rekayasa bahasa tidak dibarengi dengan 'mimpi kolektif' masyarakat penuturnya. Untuk menguraikan jawaban tersebut, pertama, saya akan menelisik akar permasalahan pelembagaan BJ yang terjadi pada masa kolonial Belanda. Potret pada masa tersebut patut disuguhkan karena tilas masa kolonial dalam pelembagaan kebahasaan BJ memegang peranan penting dan cenderung diabaikan di masa kini. Dari sanalah akar permasalahan itu muncul. Setelah itu, tulisan ini mencoba menyingkap pelembagaan dan pembinaan BJ yang timpang dan rumpang. Ketimpangan dan kerumpangan tersebut bermuasal dari kebijakan dan perencanaan BJ yang tidak didasarkan pada kejatian yang melekat pada BJ. Selain itu, impian pelestarian BJ, yang dipelopori priyayi Jawa, tidak dibarengi dengan upaya nyata pelestarian 'tradisi besar' yang beredar di kalangan elite Jawa sendiri maupun 'tradisi kecil' di masyarakat bawah. Institusi priyayi mempunyai peranan penting sebagai penjaga tradisi; tatkala institusi itu perlahan-lahan lenyap setelah 1945 (Kartodirdjo, dkk, 1987:25), maka kemungkinan lenyapnya BJ pun tak terelakkan.

\section{METODE}

Penelitian ini menggunakan metode deskriptif kualitatif, khususnya mengkaji kebijakan bahasa Jawa kurun waktu 1991-2011. Sumber data yang digunakan dalam penelitian ini adalah 
dokumen hasil Kongres Bahasa Jawa (KBJ) I-V dan dokumen kebijakan pemerintah daerah, yang terkait pelestarian bahasa. Data yang terkumpul diolah dan dianalisis berdasarkan urutan waktu dari masa kolonial hingga masa sekarang. Hasil penelitian ini berupa rekomendasi kebijakan pelestarian bahasa Jawa.

\section{HASIL DAN PEMBAHASAN}

\section{"Javanologi Belanda": Menggali Bibit Pelembagaan Bahasa Jawa di Era Kolonial}

Darusuprapta (1991) telah memaparkan perjalanan pertemuan-pertemuan pemerhati BJ sebelum diadakannya KBJ I di Semarang pada tahun 1991. Tujuannya adalah untuk menautpadukan perjalanan BJ pada masa sebelum kemerdekaan dan masa setelah kemerdekaan. Darusuprapta (1991, hlm. 35-38) memaparkan awal mula pertemuan yang membahas "nasib BJ" pada 5-8 Juli 1918 yang disebut dengan Congres voor Javaansche Cultuur ont-wikkeling. Keputusan yang paling penting dari pertemuan itu adalah pendirian Lembaga Kebudayaan Jawa, atau dikenal dengan Java Instituut. Secara berturut-turut lembaga ini mengadakan pertemuan yang disebut dengan Kongres Java Instituut selama lima kali dalam kurun waktu 1919-1930. Kemungkinan penamaan Kongres Bahasa Jawa terinspirasi dari Kongres Java Instituut ini. Sepanjang pertemuan tersebut telah dihasilkan beberapa keputusan penting dan dihasilkan program kegiatan yang terkait dengan pembinaan BJ. Beberapa keputusan pentingnya meliputi pedoman penulisan BJ dengan bahasa Latin yang dikenal dengan "Edjaan Sriwedari" (1926), pendirian "Sekolah Menengah Umum Bagian Sastra Timur" di Surakarta, dan pendirian "Sekolah Menengah Umum Bagian Sastra Barat" di Bandung. Selain itu, Kongres Java Instituut memelopori penerbitan majalah Djawa dan Poesaka Djawi pada kurun waktu 1920-1940. Di bawah ini saya akan melengkapi apa yang belum dipaparkan oleh Darusuprapta (1991), dengan tujuan agar rentetan masa lalu tentang pelembagaan dan pembinaan BJ lebih lekat-terhubung sehingga kita saat ini lebih bijak mengambil keputusan tentang kelangsungan hidup BJ.

Pelembagaan dan pembinaan BJ di masa kolonial ditandai dengan lahirnya Javanologi Belanda (Het Instituut voor de Javansche Taal) pada tahun 1832, selang dua tahun setelah Perang Jawa berakhir ${ }^{2}$ (Florida, 1995, hlm. 25; Margana, 2004, hlm. 96). Lembaga ini bertugas untuk mengumpulkan dan menyalin teks sastra Jawa yang dianggap penting dan representatif bagi kepentingan kolonial. Setelah lembaga ini menempuh separuh perjalanan, Javanologi Belanda meluaskan cakupan tugasnya, yakni penerjemahan kitab suci, bahasa Kawi, katalogisasi manuskrip, inskripsi, sastra Jawa Kuna (Kakawin), sejarah (serat dan babad), dan undang-undang lama (Margana, 2004, hlm. 104). Kehadiran proyek Javanologi yang dirintis oleh pemerintah Kolonial Belanda di bawah Gubernur Van den Bosch memberi arti penting. Karena jasa dari aktivitas Javanologi Belanda, kehadiran sastra klasik Jawa bisa kita lihat saat ini. Sementara itu, Javanologi Belanda "menanamkan dan membentuk kebudayaan elite Jawa yang secara efektif dapat mengontrol penduduk jajahan dengan menjauhkan anasir-anasir religius Islam yang telah mengilhami perlawanan Perang Jawa pada 1825-1830" (Florida, 2000, hlm. 13).

Proyek Javanologi Belanda juga didukung oleh elite Pribumi Jawa, misalnya Raden Panji Poespawilaga. Dialah yang membantu Roorda dalam menyusun Kamus Belanda-Jawa dan juga membantu merancang bangun tulisan Jawa cetak pada tahun 1839. Karena yang digunakan adalah tipe huruf dari keraton Surakarta, maka tulisan Surakarta menjadi standar penulisan Jawa. Selain itu, ada nama Poespowilogo, Sastratama, dan Ismangoon yang juga berperan aktif 
dalam aktivitas Javanologi Belanda, baik sebagai informan maupun asisten penelitian lapangan (Margana, 2004, hlm. 111-112).

Apa yang telah dipaparkan oleh Florida $(1995,2000)$ dan Margana (2004) di atas menyiratkan arti penting bahwa pelembagaan dan pembinaan BJ dilandasi oleh pembentukan kanonisasi sastra Jawa pada masa kolonial, yang pada akhirnya membentuk BJ yang berstandar. Selain itu, Javanologi Belanda juga mempunyai kepentingan, yakni mengonstruksi standar keindahan dalam sastra Jawa dan standar kebakuan dalam bahasa Jawa. Apa yang dilakukan oleh Javanologi Belanda adalah upaya preskriptif pertama kali dalam kebijakan pelembagaan dan perencanaan BJ. Hasil nyata standarisasi pada waktu itu adalah adanya standar huruf Jawa Surakarta sehingga Surakarta menjadi pusat (central), sedangkan daerah yang lain menjadi pinggiran (peripheral). Hal penting lainnya adalah peranan elite pribumi Jawa dalam keikutsertaannya dalam membentuk standar BJ yang baku. Jejak mental kolonial inilah yang memerangkap cara pandang kita dalam melihat BJ, yang masih menggunakan Surakarta sebagai "Standar Baku Penggunaan BJ". Hal ini adalah cara pandang elite yang mengabaikan BJ yang beredar di dusun/di kampung, ragam dialek yang beraneka ragam, baik ragam Jawa Timuran maupun Pesisiran. Pembahasan tentang ini secara rinci akan dijelaskan di subbab "Pemusatan Dialek Surakarta-Yogyakarta dan Peminggiran Dialek-Dialek yang Lain”.

\section{Dari Institusi ke Intuisi}

Kebijakan pemerintah kolonial Belanda yang cenderung preskriptif dengan mengabaikan kenyataan bahasa Jawa yang berkembang di masyarakat secara pasti akan mengakibatkan pembekuan BJ. Secara tersirat Ki Padmosusastra melawan hal tersebut dengan menerbitkan serial bahasa sehari-hari yang digunakan oleh petani di Jawa pada tahun 1896, 1900, 1907, dan 1911 (Margana, 2004, hlm. 112). Selain itu, ia juga pembuka gerbang keraton yang tak terjamah oleh masyarakat awam melalui penyebaran buku-buku karya Mangkunegara IV, seperti Salokatantra, Tripama, Wedhatama, dan karya yang lain agar bisa dijangkau oleh masyarakat di luar keraton (Supardi, 1961, hlm. 9). Menilik gerak Ki Padmosusastra tersebut, ia berperan sebagai "jalan penghubung" antara keraton/kolonial dan masyarakat awam. Ki Padmosusastra juga menulis risalah yang berjudul Tatacara: Adat Sarta Kalakuwanipun Tiyang Jawi ingkang Taksih Lumengket dhateng Gugontuhon (Tata cara: Adat dan Perilaku orang Jawa yang Masih Lekat pada Tahayul (1907). Atas upaya tersebut Ki Padmosusastra tidak hanya mempunyai perhatian besar terhadap sastra dan BJ saja, tetapi juga tradisi masyarakat kecil yang masih berlaku waktu itu. Tak berlebihan apabila Pamberton (1994, hlm. 137) menjulukinya Java's first modern ethnografer.

Secara tersirat Ki Padmosusastra menginginkan BJ tetap hidup di tengah masyarakat tanpa harus diletakkan pada istana yang megah, tetapi jauh dari penuturnya. Ia menginginkan BJ kembali pada intuisi penuturnya, tanpa harus dilembagakan (institusi) yang menjauhkan dari penuturnya. Terkait dengan hal tersebut Supardi (1961, hlm. 11), penulis biografi Ki Padmosusastra, menambahkan Ki Padmosusastra pantjen dudu pujangga lan ija dudu sastrawan, mung wong mardika kang marsudi kasusastran Djawa 'Ki Padmosusastra memang bukan seorang ahli bahasa dan sastrawan, melainkan hanyalah orang merdeka yang merawat keberlangsungan bahasa dan sastra Jawa.' Frasa wong mardika 'orang merdeka' mengindikasikan bahwa Ki Padmosusastra mencoba menepis desakan dan tuntutan kolonial serta berpikir-berpendapat secara bebas walaupun ia seorang pegawai kolonial. Secara implisit, Ki Padmosusastra ingin mengatakan bahwa kebijakan BJ jangan didasarkan pada pendekatan 
institusi yang preskriptif, yang waktu itu dilakukan oleh pemerintah kolonial Belanda. Seyogyanya BJ mendasarkan diri pada intuisi penuturnya. Pelajaran penting dari telaah sekelumit sejarah perjalanan BJ di atas adalah memperhatikan kelestarian intuisi penutur atau merawat keberlangsungan penutur BJ menjadi pijakan dasar dalam kebijakan perencanaan $\mathrm{BJ}$; dan Ki Padmosusastra (wafat 1 Februari 1926) telah memelopori ihwal tersebut.

Mengapa dasar kebijakan perencanaan BJ berpusat pada pelestarian intuisi penuturnya yang bersifat deskriptif? Intuisi kejawaan pernah dibahas secara sarkastik oleh Poerbatjaraka (1952, hlm. 4-5) tatkala ia mengkritik terjemahan Serat Ramayana (Jawa Kuno) yang dilakukan oleh Kern dan Juynbol secara tidak sempurna. Ketidaksempurnaannya karena kedua cendekia tersebut tidak mampu menembus ke dalam intuisi kejawaan (boten saged dumugi ing raos). Poerbatjaraka berpendapat bahwa yang mampu menembus intuisi kejawaan (raos Djawi) hanya penutur asli Jawa. Sejalan dengan Poerbatjaraka, Patmoesoekotjo (1987, hlm. 83) menulis tentang menggugah kembali intuisi kejawaan (Nenangi Raos Jawi). Membangkitkan kembali intuisi kejawaan menjadi penting karena BJ didasari oleh kompetensi anasir-anasir lembut rasa (mumpuni dhateng saliring raos) yang melekat pada diri penuturnya (language faculty). Tidak heran leksem yang terkait dengan "rasa" sangat kaya dan beragam dalam BJ, yakni ada 14 macam ungkapan (Uhlenbeck, 198, hlm. 180; Sudaryanto, 1989, hlm. 92). Kadarisman (2008, hlm. 231-232) dengan cantik menggunakan simbol "akar-tunjang budaya Jawa" untuk melambangkan intuisi kejawaan yang disebutnya sebagai "filsafat rasa". Sudaryanto (1989, hlm. 94) menandaskan bahwa dalam BJ aspek rasa, aspek batin, immaterial merupakan sesuatu yang menonjol. Pengalaman hidup yang dihayati oleh masyarakat Jawa berkisar pada "pengalaman yang batiniah, yang immaterial, dan kerasaan". Kadar kerasaan dalam BJ pada aras fonologi dan morfologi mewujud dalam banyaknya kata yang berfonestemik ${ }^{3}$ dan kata afektif, ${ }^{4}$ misalnya pada contoh berikut.

(1) tir-itir [tir itir]

tur-utur [tur-utur]

tor-otor [tor -otor]

Secara berturut-turut fonem vokal /i/, /u/, dan / / / berkorelasi dengan nuansa arti sesuatu yang semakin besar, semakin keras, semakin kasar, dan semakin berat. Jadi, secara semantis fonem vokal /i/, /u/, dan / / yang terkandung pada contoh (1) mengemban fitur semantik yang berbeda. Apa yang dipaparkan di atas menggariskan arti penting bahwa BJ adalah bahasa yang mendasarkan diri pada ekspresi rasa yang kental dan ihwal tersebut melekat dalam struktur fonologi sampai dengan sintaksisnya.

\section{Ratap Tangis Bahasa Jawa}

Ratap tangis terhadap akan-punahnya BJ di tengah masyarakat disampaikan oleh Padmosoekotjo (1956) dalam pathine paramasastra 'matinya bahasa dan sastra Jawa'. Keprihatinan Patmosoekotjo (1987, hlm. 83) terhadap hilangnya BJ secara lugas disampaikan dengan kutipan lengkap sebagai berikut.

"memang hakikinya masyarakat Jawa itu merupakan masyarakat yang mempunyai kompetensi anasir rasa (dalam bahasa), yakni rasa yang mulia-indah. Tetapi, sangat disayangkan rasa yang indah itu semakin lama semakin terselip dan terserobot diakibatkan oleh persentuhan dengan bahasa asing lainnya dan tentu saja berbeda dan bertolak belakang dengan rasa dalam bahasa Jawa. Sudah 
banyak penutur Jawa yang tidak mampu memahami bahasa Jawa dengan baik. Padahal penguasaan rasa bahasa Jawa yang baik dapat terwujud apabila dalam keadaan batin yang jernih. ${ }^{. "}$

Pudarnya kompetensi intuitif penutur Jawa disebabkan oleh persentuhan dengan bangsa lain yang takterelakkan. Gesekan dan gerusan tersebut berakibat terkikisnya BJ dan tradisinya di tengah masyarakat. Tidak hanya Padmosoekotjo yang menyesali pudarnya BJ, tetapi juga Kadarisman (2008, 2012), Subroto, dkk (2008), dan Sumarlam (2011). Secara ringkas saya akan menyarikan tiga hal tentang lenyapnya BJ dan budayanya di tengah masyarakat: (1) meratapi sastra adiluhung yang tak terbaca, (2) menyesali sastra lisan adiluhung yang tak terpahami, dan (3) menangisi pudarnya institusi priyayi.

\section{Meratapi Sastra Adiluhung yang Tak Terbaca}

Saat ini, jika pembaca modern Jawa dihadapkan pada teks klasik Jawa (misalnya Serat Wulangreh dan Wedhatama) baik yang ditulis dalam aksara Jawa maupun huruf latin sekalipun, mereka pasti tak mampu membaca dan memahami. Ketidakmampuan orang Jawa membaca teks klasik pernah diungkapkan oleh Florida (1987) dengan judul makalah yang sarkastik "Reading the unread in Javanese literature". Florida (1987, hlm. 2) menyatakan bahwa sastra Jawa adiluhung bagi orang Jawa modern adalah mitos (the myth of the adiluhung). Hal itu disebabkan oleh kelembutan dan kedalaman rasa yang terdapat pada teks klasik Jawa yang tak mampu dijamah oleh orang Jawa modern. Selain itu, teks klasik Jawa sebagai ikon keadiluhungan hanya mampu dijamah oleh kalangan elite Jawa (priyayi), sedangkan masyarakat awam tak mampu menyentuh apalagi membacanya. Pendapat Florida ini secara implisit disanggah oleh Arps (1992, hlm. 413). Tatkala orang Jawa berhadapan dengan teks Jawa klasik, dalam hal ini tembang, ia tidak hanya menganalisis teks (analytical reading), tetapi ia juga menikmatinya (poetic reading) melalui pelaguan (nembang) yang dipraktikkan dalam kehidupan sehari-hari. Orang Jawa modern menurut Arps (1992) banyak yang melakukan poetic reading tersebut, lebih-lebih tatkala petani Jawa membajak sawah, mereka pasti melantunkan tembang yang dikenal dengan uro-uro. Ibu-ibu di pedesaan ketika menimang anaknya, mereka menembangkan salah satu bait dari sastra Jawa Klasik tersebut. Kadarisman (2009, hlm. 103-104) juga memaparkan perbedaan Florida dan Arps ini yang lebih menyoroti perbedaan pembacaan (reading comprehension) yang terjadi dalam alam kesarjanaan Barat dan Timur.

Pada saat ini orang Jawa modern tak mampu melakukan keduanya, baik menganalisis teks (analytical reading) maupun menembangkan teks klasik Jawa sebagai hiburan (poetic reading). Hal itu diperkuat oleh temuan penelitian Kadarisman (2012, hlm. 258-259) yang menyatakan tatkala anak muda Jawa membaca dan mendengar penggalan satu bait dari Serat Wedhatama hanya 21 persen yang mampu memahaminya dari satu bait tembang tersebut. Responden penelitian tersebut rata-rata mahasiswa dari berbagai disiplin ilmu yang berlatar belakang budaya Jawa dan berusia 19-23 tahun. Penelitian tersebut setidaknya mewakili kondisi kekinian generasi muda Jawa dan keadaan tersebut semakin membuat ratap tangis BJ semakin keras.

\section{Menyesali Sastra Lisan Adiluhung yang Tak Terpahami}

Kadarisman (1999, hlm. 67-71) memilah sastra lisan Jawa menjadi dua, yakni tradisi lisan yang beredar di kalangan atas (the great oral tradition) dan tradisi lisan yang berkembang di 
kalangan bawah (the small oral tradition). Tradisi lisan yang beredar di kalangan elite Jawa adalah wayang kulit, kethoprak, wayang wong, macapatan, dan panembrama, sedangkan yang beredar di kalangan bawah adalah kentrung, jemblung, wayang krucil, jedhor, ludruk, dan yang sejenis lainya. Dari segi bahasa, the great oral tradition banyak menampilkan ragam bahasa Jawa kuno, klasik yang banyak dijumpai leksikon krama-nya, sedangkan the small oral tradition menggunakan bahasa sehari-hari atau ragam ngoko (Kadarisman, 1999, hlm. 74). Karena banyak dan beragamnya jenis sastra lisan yang berkembang di masyarakat Jawa, saya akan memfokuskan pada pembahasan wayang kulit, khususnya dalam penggunaan bahasanya.

Wayang kulit oleh Geertz (1960, hlm. 262) disebut sebagai inti dari kompleksitas budaya Jawa (the center of the complex) karena ia melibatkan semua kompetensi kesenian dari seni widya (filsafat dan pendidikan), seni drama (pentas dan karawitan), seni gatra (pahat dan lukisan), seni ripta (sanggit dan kesusastraan), dan seni cipta (konsepsi dan ciptaan baru) (Sujamto, 1992, hlm. 18). Selain itu, ia merupakan cerminan filosofis yang berakar-dalam dan menyebar ke semua lapisan masyarakat Jawa. Karena itu, pemahaman wayang kulit yang baik akan mengantarkan pada pemahaman dunia batin orang Jawa dan cara pandang orang Jawa yang baik pula (Sears, 1996, hlm. 9). Orang Jawa dari kalangan priyayi biasanya menggelar pertunjukan wayang kulit tuntas-semalam. Siapa dalang yang diundang untuk pentas mencerminkan posisi sosialnya di tengah masyarakat sehingga wayang kulit memang melekat pada tradisi priyayi.

Pertunjukan wayang kulit semalam suntuk menggunakan BJ ragam krama dan ngoko, baik saat janturan, sanggit, suluk, nyandra maupun waktu goro-goro atau limbukan, yang terakhir ini banyak menggunakan ragam ngoko. Penguasaan BJ yang mumpuni merupakan prasyarat utama menjadi dalang wayang kulit. Sampai saat ini dalang Ki Narta Sabda terdepan dalam hal penguasaan BJ, baik bahasa Kawi, Jawa krama, purwakanthi (rima dan aliterasi), maupun banyolan (ungkapan guyonan). Misalnya, dalam hal mendeskripsikan postur tubuh Raden Dursasana (nyandra), Ki Narta Sabda menggunakan deskripsi sebagai berikut:

(2) Bathuké manyul 'dahinya menjorok ke depan'

Mripaté pendul 'matanya besar dan lebar'

Irungé menthol 'hidungnya bengkak'

Lambéné nggandhul 'bibirnya terbuka ke bawah'

Untuné gingsul 'giginya gingsul'

Paparan tentang tubuh Dursasana yang jelek diutarakan dengan rima akhir yang indah (-ul) sehingga pendengar atau penikmat wayang akan tertawa terkekeh mendengar deskripsi tersebut. Tidak hanya banyolan, tetapi juga kesedihan, misalnya, ungkapan kesedihan ketika Bima (Werkudara) pamit (minta izin) ke Ibu Kunthi untuk menceburkan diri ke tengah Samudra karena mendapat tugas dari gurunya (Pendeta Durna) untuk mencari Air Kehidupan (tirta pawitra mahening suci) dalam lakon Dewa Ruci. Penikmat wayang kulit dibawa larut dalam alur kesedihan yang dibawakan oleh sang dalang melalui deskripsi sebagai berikut

(3) Udan tangis banjir prihatin // saklebeting purayagung Nagari Ngamarta ingkang kaperbawan dhuhkitaning tyas para satriya agung miwah Dewi Kunthi // kerana midhanget aturing sang Werkudara déné arsa ander pati nyemlung telengé samudra // teka mangkana pangandikané Dewi Kunthi lamun arsa kawiyos anggung // magepmagep kandheg ana ing tenggak // sinartan dleweraning eluh kang leresing 
pangarasan kan an kiring // sahingga sapa kang mulat datan kuwawa hanampeni sungkawané Dewi Kunthi // kang pranyata putri linuhung. ${ }^{6}$

'Hujan tangis banjir keprihatinan di dalam Istana Negara Ngamarta yang agung dan berwibawa yang pada saat itu dihadiri para satria kerajaan yang luhur dan juga Dewi Kunthi. Kesedihan menyeruak tatkala Werkudara pamit kepada ibunya tatkala ia bermaksud minta izin untuk menceburkan diri ke tengah samudra. Dewi Kunthi tak kuasa menahan kesedihan, terbata-bata ia menahan duka yang dalam. Ada nestapa yang mengganjal tenggorokannya disertai cucuran air mata yang keluar dari kedua matanya. Siapa pun yang melihat tak akan kuasa menahan rasa haru dan nestapa Dewi Kunthi, yang sungguh seorang putri bangsawan.'

Apabila ditelisik deskripsi kesedihan yang disampaikan Ki Narta Sabda di atas banyak ditemukan penggunaan bahasa Jawa klasik (Kawi) misalnya pada kata arsa 'akan', sungkawa 'susah atau kedukaan' (Winter dan Ranggawarsita,1987, hlm.13; hlm. 259). Selain itu, bentukan prefiks $\{(\mathrm{haN})+\mathrm{V}+(\mathrm{i})\}$ sufiks juga ditemukan dalam kata hanampeni yang mempunyai bentuk dasar nampa 'menerima' atau 'menahan'. Kata-kata tersebut tidak lagi dipahami dengan baik oleh masyarakat Jawa sekarang. Sebenarnya, ungkapan kesedihan dalam deskripsi di atas akan membawa penonton wayang ikut merasakan kesedihan yang disebabkan oleh cobaan hidup yang menimpa Dewi Kunthi dan tidak sedikit yang ikut meneteskan air mata larut dalam kesedihan. Hal tersebut dialami oleh Suyanto, ${ }^{7}$ (42) penggemar dan pecinta wayang kulit dengan dalang Ki Narta Sabda. Dia juga menambahkan lakon Sawitri dan Samba Juwing yang seringkali membuatnya menangis ketika mendengar rekaman kaset wayang yang diproduksi oleh Kusuma Record dan Lokananta tersebut.

Apakah yang dialami oleh Suyanto tersebut juga dialami oleh anak muda atau masyarakat Jawa sekarang? Apakah ada rasa kenikmatan dan keharuan tatkala melihat atau mendengar wayang kulit? Hasil pengamatan saya terhadap pertunjukan wayang kulit di Ngawi akhir tahun 2014 lalu menunjukkan bahwa penonton wayang melimpah-membanjiri di awal pertunjukan, yakni mulai jejer sampai dengan gara-gara atau limbukan. Penonton menunggu sampai digelarnya gara-gara yang di dalamnya biasanya diisi dengan lawakan dan campursari. Setelah gara-gara berakhir, mereka bergegas meninggalkan pertunjukan dan yang tersisa sampai tancep kayon (berakhirnya pertunjukan wayang) hanya segelintir penonton yang berusia lanjut dan renta. Padahal inti pertunjukan wayang berada di bagian akhir, yang biasanya diiringi dengan gendhing pathet enem dan ditutup dengan ungkapan sura sudira jaya nikang rat swuh brastha tekaping ulah darmastuti, atau yang lebih pendek sura dira jayaningrat lebur dening pangastuti (kedurhakaan yang merajalela akan punah oleh sikap memaafkan).

Tidak terpahaminya penggunaan BJ dalam pentas wayang kulit mengakibatkan wayang kulit hanya dinikmati dalam arti visual dan gemelarnya, yakni lawakan dan campursari. Hal ini pula yang membuat menurunnya mutu kualitas dalang wayang kulit. Mereka tidak berorientasi pada kualitas BJ yang mumpuni dalam hal sanggit dan janturan, tetapi mereka mengandalkan pesolek artis lain, misalnya dengan mendatangkan pelawak dan biduan campursari. Mereka berdalih bahwa apa yang mereka lakukan sudah menjadi tuntutan penggemar wayang kulit saat ini. Apabila pertunjukan wayang kulit saat ini tidak ada campursari dan lawakannya, tidak akan dilihat oleh penonton. Hal ini adalah bagian strategi pemertahanan wayang kulit agar tetap eksis di tengah gempuran tuntutan pasar. 
Kesimpulan dari pemaparan di atas ialah pertunjukan wayang kulit yang sarat dengan nilai filosofis Jawa tersebut mulai sepi peminat. Padahal, di dalamnya terdapat aspek pemertahanan BJ melalui sastra pentas Jawa yang banyak menggunakan leksikon ngoko, krama, dan idiom Jawa, tetapi pertunjukan itu tidak dapat dipahami dengan baik oleh masyarakat Jawa. Apakah ini hanya terjadi pada wayang kulit saja yang mewakili the great oral tradition? Bagaimanakah dengan pertunjukan kentrung, ${ }^{8}$ yang mewakili the small oral tradition, apakah masih tetap mempertahankan penggunaan BJ sebagaimana penelitian Hutomo (1987)? Hutomo (1987, hlm. 105) menyatakan bahwa penggunaan ragam krama dan ngoko dalam pertunjukan kentrung diatur sebagai berikut: pendahuluan dan penutup cerita menggunakan ngoko, sedangkan bagian naratif menggunakan krama. Pembuka dan penutup menggunakan ragam ngoko karena kedua bagian ini mengandung wejangan yang dianggap gaib dan sakral, sedangkan penggunaan krama pada bagian naratif berfungsi menghormati pendengar yang hadir dalam pertunjukan tersebut. Ragam krama dan ngoko pada bagian percakapan disesuaikan dengan status sosial tokoh cerita. Saya menduga pertunjukan kentrung sekarang banyak diwarnai dengan guyonan" dan sudah kehilangan ruhnya sebagai "dakwah Islam di lingkungan orang-orang Islam abangan, terutama bagi mereka yang bertempat tinggal di pedesaan sekitar hutan jati daerah Tuban" (Hutomo, 1987, hlm. 195).

Pemaparan di atas menyiratkan arti penting, yakni adanya gerak pergeseran dari kedalaman nilai filosofis (adiluhung) pertunjukan menuju ke pendangkalan arti pertunjukan. Jika Florida (1986) memprihatinkan kondisi sastra klasik melalui Reading the unread in Javanese literature, maka penyesalan terhadap redupnya sastra lisan Jawa terungkap dengan listening to the uncomprehended in Javanese oral tradition. Ekspresi BJ yang terdapat dalam aspek pertunjukan tersebut lama-kelamaan redup suaranya dan hanya tinggal derit pintu pertunjukan yang ditutup serta suara tabuhan cempala yang kehilangan gaung.

\section{Menangisi Pudarnya Institusi Priyayi}

Seni tradisi klasik Jawa dan penggunaan BJ berakar kuat pada tradisi kepriyayian. Ia mencerminkan kompleks seni terpadu yang mengekspresikan nilai-nilai kepriyayian (Geertz, 1960, hlm. 288). Kayam (1992) mendeskripsikan dengan indah dan lincah bagaimana tradisi kepriyayian tersebut berakar-kuat pada masyarakat Jawa melalui novel Para Priyayi: Sebuah Novel. Priyayi adalah sekelompok elite Jawa yang melanggengkan, merawat, dan mentradisikan tata-nilai-tradisi Jawa dalam keseharian hidupnya. Penelitian Damono (2000, hlm. 386-387), yang menelaah novel-novel Jawa tahun 1950-an, menandaskan bahwa dunia yang diciptakan dalam novel Jawa pada waktu itu adalah dunia priyayi yang abangan. Seorang priyayi yang ideal adalah priyayi yang menguasai kesenian, khususnya wayang kulit. Jadi, institusi priyayi adalah lembaga yang secara alami mempunyai fungsi merawat kesenian Jawa, termasuk di dalamnya BJ. Pudarnya institusi kepriyayian secara pasti akan berimbas pada keberlangsungan hidup BJ, khususnya ragam tingkat tutur dalam BJ.

Kartodirdjo, dkk. (1987, hlm. 25) mengatakan bahwa kehidupan kepriyayian dapat dikatakan berakhir setelah Indonesia merdeka pada tahun 1945. Jumlah priyayi yang mengemban dan memelihara norma-norma dan tata nilai tradisional kepriyayian berangsurangsur berkurang. Sebagai gantinya muncullah generasi baru yang berusaha melestarikan gaya hidup kepriyayian demi statusnya, tetapi usaha itu hanya berhasil pada upacara-upacara. Etika dan makna hidup kepriyayian tidak dapat dimengerti dan diikuti oleh priyayi generasi baru. 
Generasi ini bukan pengemban dan penerus warisan budaya priyayi di masa lalu. Apa yang dikatakan Kartodirdjo (1987) dibantah oleh Teeuw (1994, hlm. 224-225). Bantahan Teeuw (1994) didasarkan pada novel yang ditulis generasi 1980-an. Misalnya, pengakuan Pariyem (Linus Suryadi) dan Canting (Arswendo Atmowiloto) masih mengusung kebudayaan kepriyayian sebagai tema utama penceritaan sehingga kehidupan priyayi masih ada sesudah 1945. Lantas apakah tesis Kartodirdjo, dkk. (1987) terbantahkan? Yang dimaksud Kartodirdjo adalah semangat kepriyayian yang merawat norma-tata-nilai kepriyayian yang di dalamya mempunyai sifat kaprawiran (baca: marwah). Sementara itu, generasi penerus priyayi tersebut memang masih ada, tetapi ia hanya menguasai lapis permukaan kehidupan priyayi saja, tidak kedalaman nilainya. Hal ini diperkuat oleh studi Errington (1988, hlm. 40-44; 1998, hlm. 40) tentang pudarnya tata-krama dan trap-trapan priyayi di Surakarta, yang ia lihat dari bergesernya tingkat-tutur di kalangan priyayi keraton Surakarta. Dari paparan di atas dapat disimpulkan bahwa institusi priyayi adalah bagian dari pelestarian BJ karena di dalamnya ada habitat yang subur, tempat bersemainya tradisi dan tata nilai BJ. Priyayi merupakan ekosistem ideal bagi tumbuh dan lestarinya BJ. Hilangnya ekosistem juga berakibat pada punahnya habitat yang ada di dalamnya. Imbas pudarnya institusi kepriyayian dalam BJ adalah goyahnya tata tingkat tutur BJ.

Keprihatinan atas kegoyahan tata tingkat tutur dalam BJ sudah banyak dibicarakan oleh para ahli BJ sejak tahun 1940 (Hoesein Djajadiningrat) dan 1958 (R. Kartoamidjojo) (Sudaryanto, 1989, hlm. 96). Makalah tentang pudarnya tata tingkat tutur dalam BJ pun senantiasa dibentangkan dalam KBJ. Studi teranyar tentang ini dilakukan oleh Subroto, dkk. (2008, hlm. 94), yang menyatakan bahwa generasi muda Jawa tidak mampu berbahasa Jawa ragam krama dan krama inggil dengan baik. Kesimpulan itu diperoleh dari serangkaian tes pengukuran kompetensi BJ yang dilakukan terhadap Generasi Muda Jawa (GMJ) yang berada di Surakarta. Hasilnya menunjukkan bahwa penguasaan kosakata ngoko, krama, dan krama inggil sangat rendah, yakni di kisaran 36,45 persen. Hal itu disebabkan oleh beberapa hal, di antaranya adalah (1) tidak ada lingkungan yang mendukung penggunaan BJ, baik di rumah, di sekolah maupun di lingkungan lainnya dan (2) tidak adanya buku panduan teknis tentang bagaimana penggunaan BJ krama dan krama inggil (Subroto, dkk. 2008, hlm. 93-94). Secara ringkas, apa yang dipaparkan dalam Subroto, dkk. (2008) merupakan keprihatinan akan lenyapnya BJ di kalangan anak muda Jawa. Apa yang dilakukan oleh Subroto, dkk. (2008) adalah meneliti spesies (BJ) yang tidak memiliki ekosistem (lingkungan kepriyayian) lagi. Hasilnya jelas, yakni punah dan langkanya BJ di lingkungannya sendiri.

Ratap tangis keperihatinan akan lenyapnya BJ memang tidak dapat dipungkiri. Meskipun BJ digunakan oleh 80 juta lebih penutur, ia tetap mempunyai potensi rawan punah (Cohn \& Ravindranath, 2014, hlm. 144). Penelitian ini menyatakan ada pergeseran yang tengah terjadi dalam generasi muda, yakni dari dwibahasawan (Jawa dan Indonesia) menjadi ekabahasawan (bahasa Indonesia saja). Lebih lanjut Cohn dan Ravindranath (2014, hlm. 144) menyatakan bahwa bergesernya kemampuan tutur generasi muda Jawa disebabkan oleh bahasa Indonesia yang semakin dominan dalam berbagai bidang. Pada tahun 1980-an, penggunaan bahasa Indonesia terpengaruh oleh BJ, sedangkan kondisi sekarang struktur gramatika BJ terpengaruh oleh bahasa Indonesia. Jika ditelisik buku-buku pelajaran bahasa Indonesia di era itu, pasti dipersoalkan pengaruh bahasa daerah terhadap bahasa Indonesia, yang mengakibatkan bentuk tidak baku (Badudu, 1984, hlm. 51), misalnya pada contoh berikut: 
(4) Tamu-tamu sudah pada duduk

'Tamu-tamu sudah duduk semua'

Tuturan di atas divonis tidak tepat karena munculnya kata pada yang bukan menyatakan preposisi, tetapi interferensi dari BJ, yakni kata padha. Banyak contoh lainnya yang menunjukkan pengaruh BJ terhadap penggunaan tuturan bahasa Indonesia. Sebaliknya, pada saat ini penggunaan BJ banyak dipengaruhi oleh bahasa Indonesia (Sumarlam, 2011, hlm. 1011), terutama dalam penggunaan frasa sebagaimana contoh di bawah ini:

(5) Saka *papat calon kang maju, Komite Pemilihan mung nglolosake Nurdin lan Nirwan Bakrie.

'Dari empat calon yang maju, Komite Pemilihan hanya meloloskan Nurdin dan Nirwan Bakrie.'

(6) Suporter bal-balan cacah ewon saka saindhenging dhaérah nggelar unjuk rasa ana *kantor PSSI ing kompleks Stadion Gelora Bung Karno Senayan, Jakarta, Rebo (23/2).

'Suporter sepak bola berjumlah ribuan dari berbagai daerah menggelar unjuk rasa di kantor PSSI di Kompleks Stadion Gelora Bung Karno Senayan, Jakarta, Rabu (23/2).'

Pada contoh (5) dan (6) di atas ada bentukan frasa yang terpengaruh oleh bahasa Indonesia, yakni *papat calon dan *kantor PSSI. *Papat calon seharusnya calon papat (urutan kata dalam pembentukan frasa BJ, Kata Benda+Kata Bilangan), sedangkan *kantor PSSI seharusnya kantoré PSSI (hubungan kepemilikan antara unsur pemilik dan termilik dalam frasa nominal BJ dengan menggunakan -él-né).

Kontestasi antara BJ dan bahasa Indonesia memang tidak terelakkan, dan saat ini dimenangkan oleh bahasa Indonesia. Selain itu, arus deras bahasa Inggris juga tak dapat dihindari karena Indonesia memasuki sesrawungan global, setidaknya semakin gencar setelah era reformasi, sehingga penguasaan bahasa Inggris menjadi tuntutan. Jadi, ada tahapan persaingan bahasa: tahap pertama persaingan BJ dengan bahasa Indonesia dan tahap kedua persaingan BJ dengan bahasa Inggris (Gunarwan, 2000, hlm. 57). Persaingan ini mengakibatkan BJ semakin terdesak dan tersungkur ke pinggir.

\section{Pencanangan Keprihatinan melalui Kebijakan Bahasa}

Melihat keterpurukan BJ di atas, maka digelarlah wadah pelembagaan kekhawatiran atau disebut juga oleh Sudaryanto (1989, hlm. 97) sebagai "pencanangan keprihatinan", yakni Kongres Bahasa Jawa (KBJ). KBJ I digelar pada tahun 1991 di Semarang dengan sengkalan mangajab mekaring kanthil sawiji. Selain sengkalan sebagai keterangan waktu pelaksanaan KBJ I (1991), sengkalan tersebut juga harapan akan kelestarian kembali BJ. Sengkalan tersebut secara literal berarti "mengharap mekarnya kembang kantil satu-satunya". Ada tiga hal dasar hasil KBJ I, yakni (1) garis haluan kebijakan, (2) substansi, dan (3) pengkajian. Garis haluan dirinci lagi menjadi delapan hal: (a) perencanaan BJ, (b) pengajaran dan susastra Jawa, (c) peranan bahasa dan susastra Jawa dalam pembentukan kebudayaan nasional, (d) pembinaan BJ di luar jalur formal, (e) BJ sebagai pengungkap seni, (f) kerja sama kebahasaan, (g) sumber daya manusia dalam pengembangan bahasa dan susastra Jawa, dan (h) sarana penunjang pembinaan dan pengembangan bahasa dan susastra Jawa (Sudaryanto,dkk, 1991, hlm. 187). BJ menjadi isu sentral yang dibahas waktu itu dalam perencanaan bahasa (language planning) atau rekayasa bahasa (language engineering). Saya menduga pemangku kepentingan bahasa Jawa berusaha 
meniru kesuksesan yang dialami bahasa Melayu (sebelum menjadi bahasa Indonesia) dengan "kasus ajaibnya" (Samuel, 2008; Steinhauer, 2000). Keberhasilan program perencanaan bahasa Melayu ini mengilhami BJ untuk melakukan hal yang serupa sehingga perencanaan BJ menjadi kata bertuah yang ampuh sebagai obat penangkal kepunahan BJ.

Sebenarnya, apakah program perencanaan BJ yang meniru bahasa Melayu merupakan hal yang sesuai dengan kejatian BJ? BJ berakar pada tradisi yang kuat dan ia adalah bahasa yang ekspresif-intuitif, sedangkan bahasa Melayu adalah bahasa lingua franca, yang mempunyai kesanggupan memenuhi fungsi sosial. Fokker (dalam Alisjahbana, 1957, hlm. 200; Steinhauer, 2000, hlm. 175-177) menyatakan bahwa bahasa Melayu adalah bahasa lingkungan otak, sedangkan bahasa daerah adalah bahasa lingkungan rasa, termasuk di dalamnya BJ. Ekspresi-intuitif ini terikat dengan akar tradisi yang melingkupi sekelilingnya (Kadarisman, 2012). Berbeda dengan BJ, bahasa Melayu memiliki kesanggupan untuk dibiakkan ke tempat mana pun tanpa harus membawa tradisinya. Inilah alasan mengapa bahasa Melayu mampu diternakkan ke semua etnis yang berbeda di Indonesia. Sebaliknya, BJ tidak mampu dibiakkan tanpa satu paket dengan tradisinya.

Bahasa Melayu dalam hal menghadapi tuntutan global lebih sanggup mengadakan penyesuaian diri. Hal ini terbukti dengan banyaknya leksem baru yang dipungut (baik pengadaptasian maupun pengadopsian) dari bahasa asing melalui pencedekiaan bahasa dan pemodernan kosakata (Samuel, 2008, hlm. 400). Selain itu, pengembangan bahasa Melayu untuk dijadikan bahasa akademik-ilmiah semakin menunjukkan kematangannya. Sementara itu, BJ tidak memiliki kesanggupan yang mumpuni dalam hal menghadapi tuntutan global. Misalnya, ia tidak memiliki perkakas yang cukup untuk mengakomodasi tulisan ilmiah. Kelemahan tersebut meliputi (1) banyak kosakata pinjaman yang diambil dari bahasa Indonesia, (2) kesulitan mengungkap definisi dari sebuah konsep ilmiah, dan (3) ketidakpercayaan diri BJ dalam penggunaan istilah popular (Djatmika, 2010, hlm. 171-173). Selain itu, BJ juga lemah dalam menghadapi tuntutan generasi muda yang senantiasa mengikuti semangat zaman, misalnya penggunaan bahasa gaul atau bahasa komunitas anak muda. Saya belum menjumpai ekspresi anak muda yang menggunakan BJ.

Di atas segalanya, BJ sangat unggul dalam ekspresi emotif. Hal ini yang menjadikan alasan kuat mengapa panggurit (penulis puisi Jawa modern) seperti Anjrah Lelono Broto memilih BJ sebagai ekspresi intuitif kepenyairannya karena ia tidak menemukan padanan yang sesuai dalam bahasa Indonesia yang mampu menampung beban makna yang ia kehendaki. Maka ia memilih BJ yang sanggup mewakili rasa kepenyairannya. Menilik kejatian dan kekhasan BJ, sudah sepatutnya dirancang perencanaan BJ yang sesuai kejatian dan kodratnya. Kebijakan BJ yang tidak dilandasi oleh kejatian dan kekhasan BJ menimbulkan beberapa ketimpangan sebagai berikut:

1. Pemusatan Dialek Surakarta-Yogyakarta dan Peminggiran Dialek-dialek yang Lain

Setelah KBJ I pada tahun 1991 bermunculanlah buku tata bahasa baku BJ, misalnya Tata Bahasa Baku Deskriptif Bahasa Jawa oleh Subroto, dkk. (1991), Tata Bahasa Baku Bahasa Jawa oleh Sudaryanto (1992), dan Tata Bahasa Jawa Mutakhir yang dipelopori oleh Balai Bahasa Yogyakarta, yakni Wedhawati, dkk. (2001). Sudaryanto (1992, hlm. 1-6) menjelaskan dengan rinci alasan penulisan tata bahasa baku BJ tersebut. Ia bukan dalam rangka "membakukan atau membaku-bakukan" BJ karena BJ bahasa yang "sudah jadi", dalam artian terpelihara fungsi utamanya di masyarakat. Sudaryanto menggunakan istilah "baku" dalam pengertian pengawetan kaidah baku yang sudah ada di masyarakat. Di sinilah muncul 
permasalahan, yang disebabkan banyaknya ragam dialek BJ atau "wajah ganda BJ". Lantas dialek atau ragam manakah yang perlu diawetkan?

Sudaryanto (1992) menyatakan ada tiga hal sebagai dasar penentuan kebakuan BJ: relevansi historis, fakta objektif kajian deskriptif, dan informasi mutakhir linguistik tipologis. Akan tetapi, dasar penentuan tersebut belum diusahakan secara maksimal untuk dilakukan. Wedhawati, dkk. (2001, hlm. 13) sudah terburu memutuskan bahwa dialek standar BJ adalah dialek Yogya-Solo. Ragam dialek Yogya-Solo dianggap yang paling luas digunakan di masyarakat dan diperkuat oleh konstruksi kolonial yang menjadikan keduanya sebagai contoh ideal kebudayaan Jawa (lihat Javanologi Belanda pada bagian atas). Lantas bagaimanakah dengan ragam dialek Jawa Timur-an, Banyumas, dialek pesisiran dan dialek yang lainnya? Pemusatan ini mengakibatkan dialek lain tersisih ke pinggir, termasuk di dalamnya soal seni tradisi.Tilas mental kolonial inilah yang masih memerangkap pemangku kepentingan BJ yang masih melihat Solo-Yogya sebagai pusat kekuasaan dan daerah yang lain sebagai pinggiran, termasuk di dalamnya soal bahasa dan seni tradisi. Kalau kita telisik dengan seksama, the great oral tradition adalah sastra lisan yang banyak berkembang di wilayah pusat kekuasaan (Solo dan Yogya), sedangkan the small oral tradition berkembang di daerah pinggiran (pesisiran, Jawa Timur-an, Banyumas, dan lain-lain). Jadi, pemusatan bahasa juga berdampak pada pemusatan seni tradisi dan berimplikasi juga pada peminggiran wilayah dialek yang lain.

Sebenarnya, apabila ancangan dari Sudaryanto (1992), yang meliputi pengkajian relevansi historis, data objektif deskriptif lapangan, dan linguistik tipologis, digunakan untuk merumuskan kebijakan BJ, saya kira nasib dialek-dialek yang lain memiliki martabat yang sama dengan dialek Solo-Yogya. Selain itu, kebijakan ini akan menghidupkan kembali tradisi yang telah mati suri dan terpeliharanya kembali BJ di tengah masyarakat. Tidak tertutup kemungkinan akan bermunculan paramasastra bahasa Jawa gagrak Jawa Timur yang dipilah lagi berdasarkan subdialeknya: gagrak Madiun-Bojonegoro-Kediri, gagrak Surabaya-Malang, dan gagrak Pandhalungan (eks-karesidenan Besuki). Pengkajian relevansi historis akan melahirkan kesangkutpaduan antardaerah di Jawa. Pendeskripsian yang memadai akan menghasilkan pemetaan kekhasan daerah masing-masing; dan semua itu akan diikuti telaah yang komprehensif tentang ciri umum bahasa Jawa dari semua dialek (kajian tipologi bahasa). Keberhasilan Bahasa Using, dari dialek pinggiran dan bahkan terkesan dialek Jawa kedesadesaan, menjadi bahasa daerah yang bermartabat di Banyuwangi patut diteladani sebagai salah satu contoh kesuksesan pemartabatan dialek pinggiran (Arps, 2010, hlm. 225).

2. Pemelajaran Bahasa Kedua yang Tidak Berpijak pada Bahasa Ibu (Daerah)

Pemelajaran bahasa kedua saat ini tidak berpijak pada bahasa ibu sebagai landasan yang kokoh sehingga mengakibatkan goyahnya bahasa ibu tatkala bahasa kedua diajarkan. Bagi penutur BJ "istilah bahasa kedua" meliputi bahasa Indonesia dan bahasa asing. Seharusnya mengajarkan bahasa Indonesia tidak boleh meninggalkan BJ. Hal ini telah diteladankan oleh Raden Koewatin Sasrasoeganda ${ }^{10}$ dalam bukunya "Alat Karang Mengarang" (1933). Pemelajaran bahasa Indonesia pun dilandaskan pada bahasa Jawa sehingga peserta didik tidak kehilangan pijakan bahasa ibunya. Berikut contoh yang dipaparkan oleh Sasrasoeganda (1933, hlm. 10-11).

(7) Salinlah kepada bahasa Melajoe

Olèhmoe mlakoe koerang rikat

Sapa djenengmoe

Kowé anaké sapa

(bahasa Jawa)

'engkau berdjalan koerang tjepat'

'siapa namamoe'

'anak siapa engkau'

(bahasa Melayu) 
(8) Salinlah kepada bahasa Djawa

$\begin{array}{ll}\text { Oesah engkau pergi } & \text { 'kowé adja loenga' } \\ \begin{array}{l}\text { Djangan menangis } \\ \text { (bahasa Melayu) }\end{array} & \text { 'adja nangis' } \\ \text { (bahasa Jawa) }\end{array}$

Contoh di atas (ejaan lama sengaja saya pertahankan untuk menunjukkan keasliannya) adalah contoh pemelajaran bahasa Melayu bagi penutur Jawa. Pemelajaran bahasa kedua yang menggunakan bahasa ibu sebagai pijakan akan mengarahkan siswa pada penguasaan bahasa kedua tanpa harus menggerus bahasa ibunya. Jadi, merancang pemelajaran bahasa kedua dengan pijakan bahasa Jawa sangat mendesak dilakukan.

\section{Regulasi Tanpa Aksi}

Ada baiknya upaya menghidupkan kembali bahasa Ibrani diambil sebagai contoh. Shohamy (2006, hlm. 70-75) memaparkan dengan ringkas-padat kisah sukses kebijakan bahasa di Israel melalui sub-bab Laws and Regulations vs. de Facto Policy: The Case of Israel. Israel dihuni oleh berbagai etnis yang berbeda, baik dari segi bahasa, suku, maupun ragam keagamaan ${ }^{11}$. Bahasa Ibrani digunakan sebagai bahasa standar (resmi) pemerintahan dan juga digunakan oleh semua etnis/imigran di Israel. Hal yang menarik adalah tak ada satu pun peraturan resmi pemerintah Israel yang terkait tentang kebijakan bahasa yang menyatakan bahwa bahasa Ibrani adalah bahasa resmi kenegaraan. Baginya bahasa adalah ideologi, yakni seperangkat praktik nilai-norma yang dipatuhi dalam keseharian. Selain itu, mereka masih taat untuk menggunakan bahasa Ibrani sebagai ekspresi ideologi yang mampu mencipta identitas Yahudi Israel (Jewish Israeli identity) dan membentangkan simbol "kami" dan "mereka". Semangat penutur Ibrani dan keadaan yang semacam ini disebut de facto practices oleh Shohamy (2006), yang mampu menjaga kelestarian dan keberlanjutan bahasa Ibrani. Bagaimana dengan kondisi kebijakan regulasi bahasa Jawa?

KBJ I-V dari tahun 1991 sampai dengan 2011 telah mendesak pemangku kepentingan untuk ikut andil dalam melestarikan BJ. Setiap rekomendasi KBJ terutama KBJ IV-V telah menginisiasi lahirnya peraturan pemerintah, baik pada tataran nasional, provinsi maupun kota/kabupaten. Hasil penelusuran saya setidak-tidaknya sudah ada peraturan di tingkat nasional, yakni Peraturan Mendagri nomor 40 tahun 2007, yang telah menggariskan kebijakan yuridis pengembangan budaya daerah. Di tingkat provinsi baik Jatim, Jateng, dan DIY telah diputuskan perda serupa. Di Jatim telah lahir Peraturan Daerah Provinsi Jawa Timur Nomor 9 Tahun 2014 tentang Penyelenggaraan Pendidikan dan diperkuat lagi dengan Peraturan Gubernur Jawa Timur Nomor 19 Tahun 2014 tentang Mata Pelajaran Bahasa Daerah sebagai Muatan Lokal Wajib di Sekolah/Madrasah. Di Jawa Tengah telah terbit Surat Edaran Gubernur Jawa Tengah Nomor 895.5/01/2005 tentang Penggunaan BJ di sekolah. Di DIY Instruksi Gubernur DIY Nomor 1/INSTR/2009 tentang Penggunaan BJ berlaku pada hari tertentu di lingkungan Provinsi DIY. Selain itu, di tiap kota/kabupaten juga dihasilkan produk hukum sebagai langkah operasional penyelamatan bahasa daerah, misalnya Surat Edaran Walikota Solo Nomor 60/421 tanggal 15 Februari 2010 tentang Penggunaan BJ di Lingkungan Sekolah. Sebenarnya tidak ada alasan bahwa penyelamatan BJ tidak ada payung hukumnya. Permasalahannya bukan terletak pada produk hukum, melainkan pada semangat menggunakan BJ. Sebenarnya tidak tepat mengangkat permasalahan bahasa yang bersifat intuitif ke ranah hukum yang bersifat normatif. Hal yang bisa dilakukan adalah dengan aksi nyata karena bahasa adalah wilayah kesadaran dan praktik yang terus-menerus. Apakah kita akan memberi sangsi bagi anak kita/peserta didik kita 
apabila mereka tidak menggunakan BJ? Apakah pemaksaan yang kita kedepankan? Saya rasa yang sesuai adalah menggugah kesadaran (lihat bagian atas nenangi raos Jawi) dan penanaman pelestarian melalui teladan. Sejatinya, redupnya penggunaan BJ juga menandakan pupusnya identitas kejawaan. Apa yang saya paparkan di atas, baik semangat ideologi bahasa Ibrani maupun produk regulasi kebijakan bahasa Jawa, merupakan dua hal yang paradoks: yang satu mengedepankan praktik nyata dan lainnya menekankan pendekatan regulasi tanpa aksi. Agar keadaan ini tidak berlarut-larut, diperlukan tindakan nyata sehingga tidak memperburuk citra negeri kita sebagai "negeri di atas kertas".

\section{SIMPULAN}

\section{Menjadikan Pelestarian BJ sebagai Mimpi Kolektif}

Apa yang telah saya paparkan di atas, yang merentang dari masa kolonial hingga masa sekarang, menandakan arti penting bahwa keterancaman kepunahan BJ, pergeseran BJ, dan pencanangan keprihatinan mendesak untuk segera ditindaklanjuti. Pembenahan BJ dilandasi oleh kebijakan bahasa yang seyogianya memperhatikan beberapa ketimpangan yang telah saya paparkan di atas. Ketimpangan dan kerumpangan utama yang terjadi dalam kebijakan BJ adalah bahwa orang yang terlibat dan bertanggung jawab terhadap kelangsungan hidup BJ hanyalah segelintir orang, yang mayoritas di antara mereka adalah kelompok priyayi Jawa. Hal itu dapat dilihat dari masa kolonial bahwa yang terlibat dalam Javanologi Belanda adalah kelompok priyayi Jawa. Selain itu, di Kongres Java Instituut pun yang terlibat di dalamnya adalah kelompok priyayi Jawa juga. Keterlibatan kelompok priyayi ini tidak hanya terjadi pada masa kolonial dan awal abad XX (Kongres Java Instituut), tetapi juga pada saat Indonesia telah merdeka, yakni dari tahun 1945 hingga awal abad XXI tetap sama. Ringkasnya, mimpi pelestarian BJ hanya menjadi mimpi segelintir elite Jawa, tetapi tidak menjadi kerisauan bagi penutur BJ lainnya. Bagaimanakah menjadikan pelestarian BJ menjadi mimpi kolektif ${ }^{12}$ setiap penuturnya, terutama generasi mudanya?

Untuk menjawab pertanyaan tersebut, saya akan menyampaikan beberapa saran tentang keberlangsungan pelestarian BJ dengan tujuan agar pelestarian BJ menjadi mimpi kolektif dari setiap penutur BJ, berikut penjelasan rincinya:

a. Perencanaan kebudayaan (cultural planning) Jawa sebagaimana diusulkan oleh Gunarwan (2000, hlm. 74) sebagai saran atas pelestarian bahasa daerah mendesak untuk segera ditetapkan dan dilaksanakan. Perencanaan kebudayaan Jawa tersebut mengacu pada "prinsip-prinsip perencanaan serta tilikan-tilikan dari perencanaan bahasa dan perencanaan sosial". Prinsip-prinsip perencanaan telah diuraikan oleh Moeliono, (1985, hlm. 15-33), yakni ada empat tahap (1) perencanaan, (2) pelaksanaan, (3) penerimaan masyarakat, dan (4) penilaian. Tahap perencanaan meliputi (a) perencana bahasa, (b) sasaran perencanaan, (c) garis haluan dalam pelaksanaan, (d) rancangan alternatif dan strategi, dan (e) pengambilan putusan. Tahapan pelaksanaan meliputi (a) pengembangan sandi bahasa, (b) pembinaan pemakaian bahasa, dan (c) masalah pemasaran. Tahap penilaian menekankan pada penilaian berkelanjutan. Dasar perencanaan bahasa yang dikemukakan oleh Moeliono di atas diadaptasi ke perencanaan kebudayaan Jawa, termasuk di dalamnya pelestarian senitradisi Jawa sebagai tempat bersemainya BJ. Hal tersebut menjadi landasan utama pelestarian BJ. 
b. Pelaksanaan KBJ, Kongres Sastra Jawa (KSJ), dan pertemuan kebudayaan Jawa lainnya mendesak untuk diselaraskan tujuan dan capaian konkretnya. Selama ini pelaksanaan KBJ tidak pernah mengevaluasi capaian dan target hasil dari KBJ sebelumnya sehingga seolaholah ada keterpisahan dan ketidakpaduan dalam setiap pelaksanan KBJ tersebut. Seringkali KBJ hanya dimaknai sebagai ratap tangis para priyayi-Jawa akan hilangnya BJ di tengah masyarakat. Ia hanya difungsikan sebagai forum lelangenan yang didanai besar oleh APBD, tetapi sedikit memberi kontribusi nyata terhadap keberlangsungan masa depan BJ.

c. Generasi muda Jawa sebagai penerus keberlangsungan BJ perlu dijadikan objek aktif sasaran pengembangan BJ. Generasi muda Jawa disudutkan pada kondisi generasi yang kurang mampu memelihara "kehalusan" dan "kemurnian” BJ (Quinn, 2010, hlm. 222). Selama ini mereka hanya disalahkan karena ketidakmampuan mereka menggunakan BJ yang baik dan benar (laras dan leres) sesuai dengan tingkat-tutur BJ, tetapi mereka tidak pernah dibina secara berkelanjutan. Proses penyadaran pentingnya pelestarian BJ ini perlu dikampanyekan secara terus-menerus, khususnya terhadap keluarga muda Jawa. Capaian konkretnya adalah keluarga muda Jawa menggunakan BJ sebagai bahasa keluarga. Seluruh anggota keluarga menggunakan BJ sebagai alat komunikasi aktif di antara mereka. Sang ibu juga menggunakan BJ terhadap anaknya sejak bayi (motherese), selama usia dini, sampai si anak menginjak usia dewasa.

d. Pembinaan, pengembangan, dan pelestarian BJ yang berkelanjutan perlu melibatkan Badan Bahasa (dulu: Pusat Bahasa) yang telah mempunyai infrastruktur yang mapan di tingkatan provinsi, yakni balai-balai bahasa, misalnya Balai Bahasa Jawa Timur, Balai Bahasa Jawa Tengah, dan Balai Bahasa DIY. Saya, dalam kaitannya dengan ini, mengkritisi rekomendasi KBJ V Surabaya (2011). KBJ V merekomendasikan terbentuknya Dewan Bahasa Jawa di tingkat Provinsi. Kalau kita tilik secara cermat, rekomendasi ini tumpang tindih dengan tugas pokok dan fungsi balai bahasa yang sudah ada. Rekomendasi KBJ VI perlu mencermati kembali tugas pokok setiap kewenangan institusi bahasa.

e. Pemelajaran bahasa kedua, baik itu bahasa Indonesia, bahasa Inggris maupun bahasa asing lainnya, didasarkan pada pijakan yang kuat pada bahasa Jawa. Untuk itu perlu dipikirkan rancangan pemelajarannya sebagaimana telah diupayakan oleh Sasrasoeganda.

Pemaparan kerumpangan dan ketimpangan kebijakan perencanaan BJ di atas menyadarkan pada kita, baik kalangan pemangku kepentingan maupun penutur Jawa dari semua kalangan, untuk ikut memikirkan kelangsungan hidup BJ. Punahnya BJ tidak hanya semata hilangnya BJ itu sendiri, tetapi juga tata-nilai tradisi kebudayaan Jawa secara keseluruhan, karena nilai kebudayaan Jawa tersebut mewujud dan bertransformasi melalui medium BJ. Darma suci pelestarian BJ itu menjadi tugas para penutur Jawa dan semua orang yang pernah lahir di tanah Jawa. Mereka mempunyai kewajiban memanggul darma suci tersebut sebagai tanda bakti terhadap Ibu Pertiwi.

\section{CATATAN}

* Penulis berterima kasih kepada mitra bebestari yang telah memberikan saran-saran untuk perbaikan makalah ini dan kepada Bapak Prof. A. Effendi Kadarisman. Ph.D., guru besar linguistik di Universitas Negeri Malang (UM), yang berkenan membaca-cermat (proof reader) artikel ini dan memberi masukansaran serta pembimbingan dengan penuh kesabaran. Artikel ini tidak akan pernah hadir tanpa diskusi 
intensif (nyantrik) dengan beliau. Akan tetapi, kekurangan yang muncul dalam tulisan ini merupakan tanggung jawab saya secara pribadi.

**Artikel ini dipresentasikan kali pertama di "Seminar Kebijakan Bahasa Pascaorba: Sebuah Penguatan Identitas?" yang diselenggarakan oleh Pusat Penelitian Kemasyarakatan dan Kebudayaan, Lembaga Ilmu Pengetahuan Indonesia (LIPI) pada tanggal 4-5 Agustus 2015.

${ }^{1}$ Javanologi Belanda digunakan untuk merujuk lembaga kebahasaan yang menangani masalah sastra dan bahasa Jawa di masa kolonial.Istilah ini berbeda dengan Javanologi yang muncul pada tahun 1984 yang diprakarsai oleh Karkono K. Partokusumo. Lembaga ini beranggapan bahwa Jawa merupakan objek kajian ilmiah logos (Margana, 2004, hlm. 88).

${ }^{2}$ Ada dua alasan yang mendasari pendirian Javanologi Belanda: (1) meniru keberhasilan Inggris selama menduduki Jawa (1811-1816), yakni memberikan perhatian pada ilmu pengetahuan dan kebudayaan masyarakat Jawa melalui hasil nyata, terbitnya History of Java oleh Raffles, dan (2) kekalahan terakhir kekuasaan Jawa yang ditandai berakhirnya Perang Jawa (1830). Kedua hal ini menginspirasi lahirnya Javanologi Belanda (Margana, 2004, hlm. 65-66).

${ }^{36}$ Kelompok bunyi (phon) yang mengandung rasa (esth) tertentu mengenai kata-kata tempat terdapatnya bunyi-bunyi itu" (Sudaryanto, 1989, hlm. 42). Fonestemik, dengan kata lain, digunakan untuk menamai fenomena bunyi-bunyi bahasa [Jawa] yang kebetulan sedang berperanan mengubah atau menambah nilai suatu bentuk lingual (Sudaryanto, 1989, hlm. 42). Sejalan dengan Sudaryanto, Subroto (2011, hlm. 7) menyatakan bahwa fonestemik adalah kata-kata yang mempunyai bunyi tertentu atau gugus bunyi tertentu yang berkorelasi dengan nuansa arti tertentu.

${ }^{4}$ Kata afektif dapat pula disebut "kata emotif" atau "kata ekspresif" atau kata "emotif-ekspresif". Istilah yang agak populer ialah "kata (berkadar atau bernilai rasa)" (Sudaryanto, 1989, hlm. 52).

${ }^{5}$ Teks aslinya sebagai berikut: Pancèn sajotisipun bangsa Jawi punika dhasaripun bangsa ingkang mumpuni dhateng saliring raos; raos ingkang adi-luhung. Nanging eman déné "raos" wau saya dangu badhé saya ketalip kesilep, margi saking ketlusupan raosing basa sanès, ingkang mesthi kémawon boten laras kaliyan raos kejawèn, satemah kathah ingkang ketilapan dhateng raosing basanipun piyambak ingkang sajatos. Mangka raos wau sagedipun kraos inggih menawi pancèn dipun-raosaken kanthi pangraos ingkang wening.

${ }^{6}$ Hasil transkripsi dari kaset wayang kulit Ki Narta Sabda lakon Dewa Ruci (1984). Produksi Kusuma Record bagian ketujuh.

${ }^{7}$ Wawancara pribadi dengan penulis ketika pulang ke kampung halaman di Ngawi pada akhir tahun 2014.

${ }^{8}$ Seni Kentrung ialah pertunjukan yang berupa teater rakyat yang beredar di Jawa Timur. Anggota seni terdiri dari seorang dalang dan beberapa panjak, yang bertugas menabuh instrumen kentrung dan memberi senggakan (Hutomo, 1987, hlm. 16).

${ }^{9}$ Dugaan saya didasarkan pada pertunjukan kentrung yang diunggah di youtube yang dimainkan oleh Tri Santoso Budoyo pimpinan Adam Sumeh dari Blitar Nglegok, yang pada tahun 2003 pentas di Universitas Negeri Malang. Dari pengamatan tersebut aspek hiburan guyonan lebih dominan daripada aspek fungsi primer kentrung.

${ }^{10}$ Ia seorang guru bahasa Melayu di Sekolah Guru di Yogyakarta. Ia menyadur buku "Tata Bahasa Melayu" karya sarjana Belanda Gerth van Wijk yang berjudul asli Spraakleer der Maleische Taal (1889). Buku tersebut diterjemahkan ke dalam bahasa Indonesia oleh T.W. Kamil pada tahun 1985 melalui proyek penerbitan ILDEP (Indonesian Linguistics Development Project), yang diprakarsai oleh Pusat Pembinaan dan Pengembangan Bahasa (sekarang Badan Bahasa) dan Universitas Leiden. Selain itu, Sasrasoeganda juga menerbitkan buku pelajaran yang berjudul Kitab Jang Menjatakan Djalan Bahasa Melajoe (1910). Buku tersebut mengalami pembaharuan (edisi revisi) pada tahun 1917. Edisi yang terakhir inilah yang diperbanyak dan dicetak ulang dengan mempertahankan aslinya (ejaan lama) pada tahun 1985 oleh Balai Pustaka. Sasrasoeganda juga tercatat sebagai orang pribumi pertama yang menulis kamus dwibahasa, yaitu Baoesastra Melajoe-Djawa (1916) (Kridalaksana, 2008, hlm. 214).

${ }^{11}$ Lebih dari 6,3 juta penduduknya menggunakan bahasa Ibrani dalam percakapan sehari-hari. 1,1 juta menggunakan bahasa Arab (81 persen Muslim, 9 persen Kristiani, dan 9 persen adalah pemeluk Druze). Bahasa Arab yang mereka gunakan terdiri dari beragam dialek dan mereka menulis dengan bahasa Arab 
modern yang terstandar (Modern Standard Arabic). Selain itu, 1 juta yang lain adalah imigran dari bekas pecahan Rusia yang menetap sejak tahun 1990-an; dan mereka juga menggunakan bahasa yang berbedabeda tergantung pada asal bahasa ibunya. Sekitar 80.000 imigran dari Ethiopia menggunakan bahasa Amharik dan Tigrinia. Ditambah lagi pekerja dari manca yang tinggal di Israel yang menggunakan bahasa beragam pula: Spanyol, Turki, Bulgaria, Afrika, dan lainnya. Di atas segalanya bangsa Yahudilah yang paling dominan, dan mereka menggunakan bahasa Ibrani dialek Yidish dalam komunikasi sehari-hari, sedangkan dalam bidang yang lain menggunakan bahasa Ibrani dialek Ladino dan Arab (Shohamy, 2006, hlm. 70-75).

${ }^{12}$ Mimpi kolektif yang saya gunakan di sini terinspirasi oleh gagasan Anderson (1983, hlm. 37; 1999, hlm. 3), yang menyatakan bahwa lahirnya bangsa Indonesia bermula dari hal yang abstrak dan imajiner (imagined community). Bangsa adalah realitas psikis. Ia belum maujud atau mujarad (abstrak), tetapi gagasan besar atau mimpi besar tentang bangsa Indonesia bermula dari teritorial psikologis (psychological territory) dan ikatan primordial persahabatan yang mendalam dan sejajar (a deep horizontal comradeship).

\section{DAFTAR PUSTAKA}

Arps, B. (1992). Tembang in two traditions: Performance and interpretation of Javanese literature. London: School of Oriental and African Studies, University of London.

Arps, B. (2010). Terwujudnya bahasa Using di Banyuwangi dan peranan media elektronik di dalamnya (Selayang Pandang, 1970-2009). Dalam M. Moriyama dan M. Budiman (ed.), Geliat bahasa selaras zaman: Perubahan bahasa-bahasa di Indonesia pasca-Orde Baru (hlm. 225-248). Jakarta: KPG.

Alisjahbana, S. T. (1957). Dari perdjuangan dan pertumbuhan bahasa Indonesia. Djakarta: PT Pustaka Rakjat.

Badudu, J. S. (1984). Pelik-pelik bahasa Indonesia. Bandung: CV Pustaka Prima.

Cohn, A. C. \& Ravindranath, M. (2014). Local language in Indonesia: Language maintenance or language shift. Linguistik Indonesia, 32(2), 131-148.

Darusuprapta. (1991). Kongres Bahasa Jawa I dalam http://journal.ugm.ac.id/jurnalhumaniora/article/view/2077/1877, diakses pada tanggal 1 Juni 2015.

Damono, S. D. (2000). Priyayi abangan: Dunia novel Jawa tahun 1950an. Yogyakarta: Bentang Budaya.

Djatmika. (2010). Upaya bahasa Jawa mengakomodasi tulisan ilmiah: Tanda-tanda impotensi atau komplikasi? Linguistik Indonesia, 28(2), 165-176.

Errington, J. J. (1998). Shifting languages: Interaction and identity in Javanese Indonesia. New York \& London: Cambridge University Press.

Errington, J. J. (1998). Structure and style in Javanese: A semiotic view of linguistic etiquette. Philadelphia: University of Pennysylvania Press.

Geertz, C. (1960). Religion of Java. Chicago and London : The University of Chicago Press.

Gunarwan, A. (2000). Peran bahasa sebagai pemersatu bangsa. Dalam Kajian serba linguistik untuk Anton Moeliono Pereksa Bahasa (hlm. 51-81). Jakarta: Unika Atma Jaya. 
Florida, N. (1987). Reading the unread in traditional Javanese literature. In Indonesia (hlm. 1$15)$.

Florida, N. (1995). Writing the past inscribing the future: History as prophecy in colonial Java. Durham \& London: Duke University Press.

Florida, N. (2000). Javanese literature in Surakarta manuscript. SEAP: Cornel University.

Hutomo, S.S.. (1987). Cerita kentrung Sarahwulan di Tuban. Jakarta: P dan K.

Kadarisman, A. E. (1999). Wedding narratives as verbal art performance: Explorations in Javanese poetics. Disertasi Ph.D. (tidak dipublikasikan). University of Hawai'i at Manoa, Honolulu, Hawai, USA.

Kadarisman, A.E. (2008). Sketsa puitika Jawa: Dari rima anak-anak sampai filsafat rasa. Dalam Pudentia (Ed.) Metodologi kajian tradisi lisan (hlm. 219-246). Jakarta: Asosiasi Tradisi Lisan.

Kadarisman, A. E. (2009). Berkenalan dengan ethnopuitika. Dalam Mengurai bahasa menyibak budaya (hlm. 97-115). Malang: UIN-Maliki Press.

Kadarisman, A. E. (2012). On diminishing local expressions in Javanese. Dalam B. U. Siregar, A. Subagyo, dan Y. Nasanius (Ed.) Dari menapak jejak kata sampai menyigi tata bahasa: Persembahan untuk Prof. Dr. Bambang Kaswanti Purwo dalam rangka ulang tahunnya yang ke-60 (hlm. 249-269). Jakarta: PKBB Unika Atma Jaya.

Kartodirdjo, S., Sudewo, \& Hatmosuprobo, S. (1987). Perkembangan peradaban priyayi. Yogyakarta: Gadjah Mada University Press.

Kayam, U. (1992). Para priyayi: Sebuah novel. Jakarta: Grafiti Press.

Laksono, K. (2011). Pangleluri basa lan dialek Jawa. Dalam Prosiding Kongres Bahasa Jawa V Surabaya.

Lewis, M. P., Simons, G. F., \& Fennig, C. D. (eds.), 2013. Ethnologue: Languages of the world, seventeenth edition. Dallas, Texas: SIL International. Online version: http://www. ethnologue.com. Diakses pada 1 Juni 2015.

Margana, S. (2004). Pujangga Jawa dan bayang-bayang kolonial. Yogyakarta: Pustaka Pelajar.

Moeliono, A. M. (1985). Pengembangan dan pembinaan bahasa: Ancangan alternatif di dalam perencanaan bahasa. Jakarta: Penerbit Djambatan.

Padmosoekotjo, S. (1956). Pathine paramasastra. Djakarta: Noordhoff-Kolff NV.

Padmosoekotjo, S. (1987). Memetri basa Jawi: Jilid I. Surabaya: Citra Jaya Murti.

Pamberton, J. (1994). On the subject of "Java". Ithaca \& London: Cornell University Press.

Poerbatjaraka, R. M. Ng. (1952). Kapustakan Djawi. Djakarta: Penerbit Djambatan. 
Quinn, G. (2010). Kesempatan dalam kesempitan? Bahasa dan Sastra Jawa sepuluh tahun pasca-ambruknya Orde Baru. Dalam M. Moriyama \& M. Budiman (eds.), Geliat bahasa selaras zaman: Perubahan bahasa-bahasa di Indonesia pasca-Orde Baru (hlm. 207224). Jakarta: KPG.

Samuel, J. (2008). Kasus ajaib bahasa Indonesia? Pemodernan kosakata dan politik peristilahan. (Terjemahan dari Modernisation lexical et politique terminologique: Le cas de l'Indonesien.) Jakarta: Kepustakaan Populer Gramedia.

Sasrasoeganda, K. (1933). Alat karang mengarang. Groningen-Den Haag-Batavia: J.B. Wolters.

Sears, L. J. (1996). Shadows of empire: Colonial discourse and Javanese tales. Durham \& London: Duke University Press.

Shohamy, E. (2006). Language policy: Hidden agendas and new approaches. New York \& London: Routledge.

Subroto, E., Dwirahardjo, M. \& Setiawan, B. (2008). Endangered krama and krama inggil varieties of the Javanese language. Linguistik Indonesia, 26(1), 90-96.

Sudaryanto. (1992). Tata bahasa baku bahasa Jawa. Yogyakarta: Duta Wacana Press.

Sudaryanto. (1989). Pemanfaatan potensi bahasa. Yogyakarta: UGM Press.

Sudaryanto, dkk. (Ed.) (1991). Prosiding kongres bahasa Jawa: Semarang 15-20 Juli 1991 (Buku I). Surakarta: Pemerintah Daerah Tingkat I Propinsi Jawa Tengah \& Penerbit Harapan Massa.

Sujamto. (1992). Wayang dan budaya Jawa. Semarang: Dahara Prize.

Supardi, I. (1961). Ki Padmasusastro. Surabaja: Panjebar Semangat.

Sumarlam. (2011). Potret pemakaian bahasa Jawa dewasa ini serta pembinaan dan pengembangannya: Sebuah pergeseran struktur gramatika dan tingkat tutur. Dalam Pidato pengukuhan guru besar Fakultas Sastra dan Seni Rupa. Surakarta: Universitas Sebelas Maret.

Steinhauer, H. (2000). Bahasa Indonesia dan bahasa daerah di Indonesia. Dalam B. Kaswanti Purwo (ed.) Kajian serba linguistik untuk Anton Moeliono pereksa bahasa (hlm. 175195). Jakarta: Unika Atma Jaya dan BPK Gunung Mulia.

Uhlenbeck, E. M. (1978). Kajian morfologi bahasa Jawa. Jakarta: Penerbit Djambatan.

Teeuw, A. (1994). Tentang priyayi, sastra, dan sejarah. Dalam Indonesia antara kelisanan dan keberaksaraan (hlm. 224-249). Jakarta: Pustaka Jaya.

Wedhawati, dkk. (2001). Tata bahasa Jawa mutakhir. Yogyakarta: Pustaka Kanisius.

Winter, C. F. \& Ranggawarsita. (1987). Kamus Kawi - Jawa (Cetakan ke-9). Yogyakarta: Gadjah Mada University Press. 